\begin{tabular}{|l|l|l|}
\hline \multicolumn{2}{|c|}{ PublisherInfo } \\
\hline \hline PublisherName & $:$ & BioMed Central \\
\hline \hline PublisherLocation & $:$ & London \\
\hline \hline PublisherImprintName & $:$ & BioMed Central \\
\hline \hline
\end{tabular}

\title{
Whole-genome sequencing of a spirochaete
}

\begin{tabular}{|l|c|l||}
\hline \multicolumn{2}{|c|}{ ArticleInfo } \\
\hline \hline ArticleID & $:$ & 4760 \\
\hline \hline ArticleDOI & $:$ & $10.1186 /$ gb-spotlight-20030424-01 \\
\hline \hline ArticleCitationID & $:$ & spotlight-20030424-01 \\
\hline \hline ArticleSequenceNumber & $:$ & 112 \\
\hline \hline ArticleCategory & $:$ & Research news \\
\hline ArticleFirstPage & $:$ & 1 \\
\hline \hline ArticleLastPage & $:$ & 2 \\
\hline \hline & & RegistrationDate : 2003-4-24 \\
\hline ArticleHistory & $:$ & OnlineDate \\
\hline \hline ArticleCopyright & $:$ & BioMed Central Ltd2003-4-24 \\
\hline \hline ArticleGrants & $:$ & \\
\hline \hline ArticleContext & $:$ & 130594411 \\
\hline \hline
\end{tabular}




\section{Cathy Holding}

Email: cathy.holding@bbsrc.ac.uk

Spirochaetes are a large and diverse group of bacteria that are remarkable not only for their visual strangeness, being helical, but also for their ability to live in a variety of environments. Several genera are pathogenic, causing widely differing diseases including syphilis and Lyme disease. Leptospira interrogans causes leptospirosis in man, characterised by sudden haemorrhage resulting in severe or fatal damage to the liver, kidney and lungs. Analysis of the genetics of the spirochaetes lags behind that of other bacteria due to the complexity of growth requirements and relatively long generation times.

In 24 April issue of Nature, Shuang-Xi Ren and colleagues from a large collaboration including Chinese, French and US scientists (Nature 2003, 422:888-893), provide the groundwork for a thorough understanding of the mechanisms of virulence and pathology in the leptospirosis agent.

Ren et al. use whole-genome sequencing to analyse a specific strain of Leptospira interrogans, and predict and compare protein coding sequences within and outside the spirochaete phylum. By careful use of the information generated, they produce a metabolic-pathways map, a functional-genomics map, analyses of the chemotaxis system and of lipopolysaccharide synthesis, and a discussion on the evolution of this human pathogen from an environmental bacterium.

Although leptospirosis responds to antibiotics, it is still a significant threat in developing countries. Understanding the mechanisms that result in pathogenesis, and the physiological relationships between disparate diseases caused by members of the same phylum, could provide additional approaches to the treatment of a range of diseases.

\section{References}

1. Genetics of motility and chemotaxis of a fascinating group of bacteria: the Spirochetes.

2. Nature, [http://www.nature.com]

3. LipL21 Is a Novel Surface-Exposed Lipoprotein of Pathogenic Leptospira Species 